\title{
ВИВЧЕННЯ ДОСВІДУ ЗАСТОСУВАННЯ НЕІНВАЗИВНИХ МЕТОДІВ ДЛЯ ОЦІНКИ ФУНКЦІОНАЛЬНОГО СТАНУ ОРГАНІЗМУ ПРИ ФІЗИЧНИХ ТА ПСИХОЕМОЦИЙНИХ НАВАНТАЖЕННЯХ (ОГЛЯД ЛІТЕРАТУРИ)
}

\author{
Жалдак Анастасія ${ }^{1}$, Іванько Олеся ${ }^{2}$, Депутат Юрій ${ }^{3}$ \\ ${ }^{1}$ Старший лікар відділення санітарно- епідеміологічного нагляду санітарно- \\ епідеміологічного відділу військової частини А4520, м. Львів, Україна \\ ${ }^{2}$ Керівник Науково-дослідного інституту проблем військової медицини Української \\ військово- медичної академії, м. Київ, Україна \\ ${ }^{3}$ Науковий співробітник Науково-дослідного інституту проблем військової медицини \\ Української військово-медичної академії, м. Київ, Україна
}

Анотація. Оаляд літератури присвячений питанням особливостей професійної діяльності військовослужбовців новоствореного роду військ - Сил спеціальних операцій Збройних Сил Украӥни, зокрема, при відборі та підготовці фахівців на кваліфікаційному курсі спеціальних операцій Збройних Сил Украӥни. Узагальнено дані літератури стосовно реакцій організму до фізичних та психоемочійних навантажень. При цььому звертається увага, щзо результатом первинної метаболічної відповіді організму на екстремальні чинники (фізичні навантаження та стрес) є активація вільно радикального окиснення ліпідів мембран. Біохімічним маркером активації иьього процесу можуть слугувати поліненасичені жирні кислоти, а їх якісні і кількісні зміни в біологічних рідинах характеризують функиіональний стан організму при фізичних $i$ психоемоиійних навантаженнях.

Систематизація літературних джерел та підходів до вирішення проблеми застосування неінвазивних методів дослідження біологічних рідин засвідчила, щзо на основі даних біохімічного дослідження циих рідин можна охарактеризувати рівень активачії перекисного окиснення ліпідів, тобто метаболічних пристосувальних реакиій в організмі.

Ключові слова: військовослужбовці, фізичні навантаження, перекисне окиснення ліпідів, неінвазивні методи, біологічні рідини.

Вступ. У зв'язку з інтенсифікацією динаміки військових дій, проявами терористичної діяльності, політичним станом у світі, - в арміях багатьох країн ще в середині двадцятого століття були сформовані окремі підрозділи Сили спеціальних операцій (ССО). Так, згідно з польовим статутом FM 31-21 Сполучених Штатів Америки (США) ССО можуть діяти в умовах війни, військового конфлікту і в мирний час.

Після взяття зовнішньополітичного курсу на євроатлантичну інтеграцію у 2016 році в Україні також створено окремий рід військССО. Завдання, що покладаються на ці фор- мування $\epsilon$ досить різнонаправленими та складними (Фуртес \& Ткачук, 2010; Ясенчук, 2018). Професійна діяльність військовослужбовців ССО часто передбачає виконання ними завдань за призначенням в екстремальних умовах. Поставлені задачі виконуються при дефіциті часу та інформації, супроводжуються постійним ризиком і наявністю загрози для життя (Ясенчук, 2018; Deuster et al. 2016; Montain \& Young, 2003). У зв'язку з переліченим вище, відбір кандидатів для підготовки i проходження подальшої служби в ССО є досить ретельним. При цьому найбільші вимоги ставляться до їх фізичної та психологічної

Cite as: Studying the experience of application of non-invasive methods to assess the functional state of the organism under physical and psychoemotional loads (literature review) 
стійкості і витривалості (Фуртес \& Ткачук, 2010; Romanchuk et al., 2012).

Підготовка військовослужбовців для ССО в Україні відбувається з 2016 року за адаптованою програмою армій країн НАТО і має назву “Кваліфікаційний курс спеціальних операцій" (Special Forces Qualification Course - SFQC або Q-курс). SFQC триває близько шести місяців і складається з шести фаз.

У зв'язку з тим, що перед більшістю армій зарубіжних країн залишається до кінця не розв'язаним, а в Україні взагалі було не дослідженим, питання енергетичних витрат та ïx компенсації у військовослужбовців ССО під час навчально-тренувального процесу, перед Українською військово-медичною академією (УВМА) Міністром оборони України було поставлено завдання щодо вивчення даної проблеми. У період з 2018 по 2019 рік виконувалася науково-дослідна робота “Фізіолого-гігієнічне обгрунтування нутрієнтного складу добового раціону харчування військовослужбовців сил спеціальних операцій” (НДР), в результаті якої були встановлені фактичні енерговитрати (Депутат \& Гуліч, 2020) та надані обгрунтовані рекомендації щодо їх компенсації. В ході виконання вказаної НДР було виявлено, що за 5-ти річну історію проведення Q-курсів у 3С України закінчити їх у різні роки змогли лише від 10 до 20\% військовослужбовців, які брали в них участь.

I хоч кандидати перед початком Q-курсу проходять військово-лікарську комісію та психофізіологічне тестування, найбільше випадків передчасного покидання Q-курсу, як правило, відбувається під час 14-ти денної першої фази, яка має назву “Фаза оцінки та відбору” (Special forces assessment and selection - SFAS). Головна мета цієї фази - виявити фізично та психологічно не готових осіб до подальшої служби в ССО. Кожен кандидат має зрозуміти, чи зможе він виконувати подібні завдання в майбутньому та як його організм реагує на тривалі інтенсивні фізичні навантаження та стресові ситуації.

Протягом цього етапу даються максимальні навантаження, наприклад, тридцяти кілометровий марш-кидок у повному спорядженні, переміщення вантажу по болоту, піску та пересіченою місцевістю. Всі випробування проводяться в різних погодних умовах, незалежно від часу доби, на різній місцевості і супроводжуються психологічним тиском (Фуртес \& Ткачук, 2010).

Встановлено, що відбір військовослужбовців ЗС України в першій фазі відбувається лише на основі визначення здатності до виконання комплексу фізичних вправ, що передбачені програмою підготовки. Проте, сам факт проходження першої фази не може дати повну оцінку функціонального стану організму, виявити дезадаптаційні зрушення чи показати приховані патологічні процеси, котрі можуть проявитися найближчим часом в послідуючих фазах підготовки. Тому передчасне залишення Q-курсу часто може бути викликане погіршенням стану здоров'я військовослужбовців, що, відповідно, зумовлює економічні збитки на їх лікуваня чи реабіллітацію, а також у вигляді затрачених коштів під час незавершеної підготовки.

У зв'язку з цим, не дивлячись на успішне завершення вищезгаданої НДР, перед науковцями УВМА залишається не розв'язаним завдання щодо дослідження метаболічних реакцій в організмі курсантів на етапі першої фази Q-курсу для раннього виявлення осіб 3 проявами дезадаптаційних зрушень. Це дасть змогу командуванню ССО ЗС України своєчасно приймати управлінські рішення стосовно таких військовослужбовців для збереження їх здоров'я.

Мета - вивчити дані літератури щодо застосування неінвазивних методів дослідження біологічних рідин для вивчення метаболічних реакцій організму при довготривалих інтенсивних фізичних і психоемоційних навантаженнях.

Матеріали та методи. Використано джерела літератури та матеріали патентного пошуку. Застосовано методи: інформаційно-пошуковий, бібліографічний, порівняльного аналізу.

Результати та їх обговорення. Низкою досліджень показано, що фізичні і психологічні навантаження у військовослужбовців ССО можуть сягати максимуму функціональних можливостей організму (Фуртес \& Ткачук, 2010; 
Ясенчук, 2018) і подібні за інтенсивністю до важкого тренувального процесу в спорті. Так, автори (Deuster et al., 2016; Montain \& Young 2003) називають військовослужбовців ССО воїнами-атлетами, оскільки їх витрати енергії при виконанні завдань за призначенням мають схожість зі спортсменами більшості видів спорту і перевищують показники енерговитрат середньостатистичної особи в 3-6 разів.

B роботах (Ясенчук, 2018; Deuster et al., 2016) відмічається, що підготовка військовослужбовців-курсантів на Q-курсі за фізичними та психоемоційними навантаженнями подібна до спортивних змагань, а їх фізіологічні процеси адаптації, тренування, втоми, відновлення в ході відбору та підготовки співставні 3 такими у спортсменів під час змагань чи тренувань (Петрачков, 2014; Islamov, Dmitriev, Bogz \& Tsygankov, 2016; Viru, 2017; Романчук, 2018; Шахлина, Коган, Терещенко, Тищенко \& Футорный, 2016).

При виконанні фізичної роботи в організмі відбувається структурно-функціональна перебудова на всіх рівнях: клітинному, організменному, системному (Осіпов, 2013). Метою цього процесу є створення оптимальних умов, насамперед, для роботи м'язів, за рахунок збільшення їх енергопостачання та функціонування організму в цілому (Осипенко, 2007). Необхідні для цього біохімічні та фізіологічні зрушення виникають під впливом нервово-гормональної регуляції. Наслідком є збільшення швидкості кровообігу і легеневої вентиляції, що призводить до кращого постачання м'язів та інших органів, що мають відношення до м'язової діяльності, киснем і енергетичними субстратами.

На клітинному рівні під впливом нервово-гормональної регуляції збільшується вироблення енергії (Ярушин, 2017; Осіпов, 2013). В основі цього явища лежить зміна спрямованості метаболізму в клітинах: значно прискорюються реакції катаболізму при одночасному зниженні швидкості анаболічних процесів (головним чином, синтезу білків) (Петрина \& Юшина, 1989; Селезнева \& Иванцова, 2019). Таким чином, забезпечення роботи м'язів здійснюється шляхом мобілізації вуглеводів i жирів 3 депо та їх ефективне окиснення з утво- ренням аденозинтрифосфорної кислоти (АТФ) (Остапченко, Синельник \& Компанець, 2016).

При підвищенні інтенсивності чи тривалості фізичного навантаження збільшується артеріальний тиск, частота пульсу, вміст адреналіну та інших активуючих гормонів у крові, а також зростає потреба в енергетичному забезпеченні, збільшується потреба в кисні, як необхідного субстрату продукції енергії (Ярушин, 2017). Оскільки запас вуглеводів обмежений, значна частина енергії при таких навантаження утворюється за рахунок окиснення жирів, на долю яких припадає від 10 до 50\% від загальних витрат енергії (Фабрі \& Чернов, 2014; Zolotareva \& Volchkova, 2015). При цьому, мобілізація ліпідів і переключення метаболізму з вуглеводного обміну на ліпідний являється досить частою формою відповіді на зовнішні чинники, зокрема фізичні і стресові (Афонина \& Куюн, 2000; Волков, Несен, Осипенко \& Корсун, 2000; Коломеец, Новоженов, Белоногов \& Волчек, 1997) і свідчить про адаптаційний характер ліпідного обміну (Варус, Брюзгіна, Белов, Соловська \& Депутат, 2007; Варус та ін., 2010).

У разі виснажливих фізичних та психологічних навантажень, зміни в метаболізмі ліпідів можуть носити патологічний характер і бути причиною порушень інших видів обміну речовин i багатьох функцій організму. Так, при збільшенні інтенсивності фізичних навантажень, одночасно з переліченими вище метаболічними процесами та біохімічними реакціями відбувається активація перекисного окиснення ліпідів (ПОЛ). Процеси ПОЛ потрібні для нормального функціонування біохімічних і фізіологічних систем і в нормі постійно відбуваються у всіх клітинах живих організмів, беручи участь в синтезі відповідних гормонів, медіаторів, ейкозаноїдів та ін. (Орел, 2010; Фабрі \& Чернов, 2014). Проте, при підвищенні інтенсивності цього процесу та відповідно збільшенні вироблення продуктів ПОЛ - окиснювальних радикалів: перекису водню, гідроксильного радикала, синглетного кисню (Говоруха \& Шнайдерман, 2016; Трохимович, Кишко, Сливка \& Ганич, 2011; Фабрі \& Чернов, 2014), відбувається пошкодження клітинних мембран, порушується 
їх осмотична резистентність, збільшується проникність капілярів та ін. (Говоруха \& Шнайдерман, 2016; Остапченко, Синельник $\&$ Компанець, 2016). В результаті цей процес може призвести до віддалених вільнорадикальних патологій: атеросклероз, ішемічна хвороба серця (IXC), артеріальна гіпертензія (Трохимович, Кишко, Сливка \& Ганич, 2011). Інтенсивність процесів ПОЛ може зростати і проявлятися у нетренованих людей навіть під впливом фізичних навантажень невеликої потужності, які для них вже є стресовими.

Отож, активація вільнорадикального окиснення ліпідів мембран може бути показником первинної метаболічної відповіді організму на екстремальні чинники (фізичні навантаження та стрес) (Мусієнко, 2009; Остапченко, Синельник \& Компанець, 2016).

Оскільки рівень активації ПОЛ може слугувати показником функціонального стану організму, то, на нашу думку, вивчення впливу фізичних навантажень на процеси ПОЛ в організмі кандидатів під час проходження Q-курсу могло би стати підгрунтям з розробки критеріїв оцінки спроможності військовослужбовців до виконання завдання за призначенням в надскладних умовах при подальшій службі в СCO.

Найчастіше біохімічний контроль оцінки рівня активації процесів ПОЛ проводять за показниками продуктів ліпопероксидації (малонового діальдегіду, дієнових кон'югатів). Проте, не лише продукти ПОЛ можуть мати діагностичне значення.

Встановлено, що субстратами ПОЛ $є$ фосфоліпіди біомембран клітин, зокрема, поліненасичені жирні кислоти (ПНЖК), котрі входять до їх складу (Орел, 2010; Остапченко, Синельник \& Компанець, 2016). Якісні і кількісні зміни ПНЖК в біологічних рідинах можуть мати таке ж діагностичне значення, як і продукти ПОЛ, та можуть бути інформативним тестом у клінічній і лабораторній діагностиці. У дослідженнях авторів встановлена діагностична значимість використання показників рівня ПНЖК в крові як маркера патологічних станів (Лизогуб, Пануша \& Брюзгіна, 2016; Мякишева, Колсанов, Власов $\&$ Соколов, 2017), а в деяких працях встанов- лено зміну рівня ПНЖК при фізичних навантаженнях (Варус, Брюзгіна, Белов, Соловська \& Депутат, 2007; Варус та ін., 2010; DelgadoPovedano, Calderón-Santiago, Castro \& PriegoCapote, 2018).

Загальновизнано, що в лабораторній діагностиці основною біологічною рідиною для визначення будь-яких показників, і ПНЖК в тому числі, $\epsilon$ кров. Проте, взяття зразків крові у військовослужбовців Q-курсу в умовах жорстких режимних обмежень і дефіциту часу, швидше за все, буде неможливим. Перед усім - це інвазивний метод, який вимагає дотримання правил асептики. По-друге, неможливо взяти пробу безпосередньо під час виконання фізичних вправ чи в будь-який період доби, наприклад, після прийому їжі. По-третє, для роботи 3 нативними зразками крові виділяється мало часу, оскільки кров має властивість до згортання. Також не слід забувати про біоетичні принципи, спираючись на які, людина може обгрунтовано відмовитися від будь-яких медико-біологічних досліджень, а особливо інвазивних. Як свідчать попередні дослідження, проведення масових профілактичних оглядів багаторазово супроводжувалися відмовою від взяття зразка крові, оскільки здоровій людині важко довести таку необхідність (Горіла, 2009).

Тому останнім часом відбувається перегляд методів біохімічного аналізу в бік розширення спектру дослідження біологічних рідин, особливо поту та слини, отриманих неінвазивним шляхом (Меньшиков \& Лукичева, 1996; Мякишева, Колсанов, Власов \& Соколов, 2017).

Дослідженнями авторів встановлено, що зміни ліпідних показників в поті та сироватці крові є односпрямовані, а отже проби поту можна застосовувати для оцінки порушень ліпідного метаболізму (Лізогуб, Пануша \& Брюзгіна, 2016).

До складу поту входять мікроелементи $(\mathrm{K}+$, $\left.\mathrm{Ca}_{2}+, \mathrm{Mg}_{2}+, \mathrm{Fe}_{2}\right)$, продукти мінерального, білкового та ліпідного обміну, зокрема жирні кислоти, що можуть мати діагностичне значення (Baker \& Wolfe, 2020; Calderón-Santiago, Priego-Capote, Jurado-Gámez \& Castro, 2014; Lindsay \& Wolfe, 2020). В дослідженні автоpiв Calderón-Santiago, Priego-Capote, Jurado- 
Gámez \& Castro (2014) показано, що піт, окрім жирних кислот 3 коротким ланцюгом містить також жирні кислоти 3 довгим ланцюгом та ненасичені жирні кислоти.

Піт може відображати як місцеві, так і системні біохімічні зміни у відповідь на хворобу чи втручання i дослідження медіаторів потових ліпідів підтверджують цю здатність (Agrawal, Sivamani \& Newman, 2019; Agrawal, Hassoun, Foolad, Pedersen, Sivamani \& Newman, 2017; Lindsay \& Wolfe, 2020).

Досліджено, що на склад поту впливають не тільки концентрації позаклітинних розчинених речовин, але й механізми секреції та/або реабсорбції, швидкість потоку поту, побічні продукти метаболізму потових залоз, забруднення поверхні шкіри десквамованими клітинами епідермісу та виділення шкірного сала (Baker \& Wolfe, 2020; Kand'ár, Drábková, Andrlová, Kostelník \& Čegan, 2016). Склад поту не однаковий на різних ділянках шкіри і залежить від загального стану організму, типу харчування, дії інших факторів - температури, вологості повітря оточуючого середовища, тривалості і інтенсивності фізичних навантажень (Гоженко, Зацерклянный \& Цепколенко, 2006).

Піт є перспективною біологічною рідиною, його клінічне використання вимагає знання складу та розробки аналітичних методів для його характеристики. В одному з досліджень були порівняні різні методи підготовки зразків для покращення виявлення метаболітів поту в людей після помірних фізичних навантажень. Були виявлені ліпіди, бензеноїди та інші метаболіти, такі як алкалоїди та етаноламіни. Оскільки більшість ідентифікованих сполук $\epsilon$ метаболітами, які беруть участь у ключових біохімічних механізмах, це дослідження дало нові можливості для розширення застосування поту як джерел метаболітів-біомаркерів патологій або специфічних процесів, таких як зневоднення при фізичних навантаженнях або харчовий дисбаланс (Delgado-Povedano, Calderón-Santiago, Castro \& Priego-Capote, 2018; Krsota, 2007).

Слина, як рідина для аналізу (Лихо рад \& Шаковец, 2013), також являється унікальним біологічним середовищем, на 99\% складається $з$ води і лише на 1\% 3 мінеральних і орга- нічних речовин, які і визначають іiі унікальні властивості і функції. Встановлено, що в рідині ротової порожнини міститься широкий спектр білків, жирних та нуклеїнових кислот, а також електроліти, ферменти, гормони, інші регулятори. Це дало можливість досліджувати іiі в якості біологічного середовища для оцінки фізіологічних процесів і патологічних станів не тільки ротової порожнини, а й всього організму.

Існує метод використання слини в якості альтернативи крові для діагностики і моніторингу лікування цукрового діабету, захворювань ротової порожнини та ін. При цьому зсуви біохімічних показників в слині більш значущі, ніж в сироватці крові, що робить дане біологічне середовище кращим для скринінгу, діагностики деяких патологічних станів (Лихорад \& Шаковец, 2013; Мякишева, Колсанов, Власов \& Соколов, 2017).

В роботах інших авторів, вивчалися методи дослідження слини для характеристики функціонального стану організму під час м'язової діяльності. Досліджувалися зміни показників титру лізоциму в слині, $\mathrm{pH}$, амілази, молочної кислоти, компонентів імунної системи (IgA). Було встановлено, що у спортсменів істотні фізичні навантаження призводять до зниження титру лізоциму, зрушення $\mathrm{pH}$ слини в кислий бік, призводять до підвищення активності амілази, зростання вмісту молочної кислоти (Lindsay \& Wolfe, 2020).

Висловлена думка, що слина володіючи меншою, ніж кров, буферною ємністю, краще відображає порушення кислотно-лужної рівноваги в організмі спортсмена чи звичайної людини, яка займається фізичними навантаженнями (Гоженко, Зацерклянный \& Цепколенко, 2006; Лихорад \& Шаковец, 2013).

Отож, вчені та практики застосовують різні методи для збору біологічних рідин отриманих неінвазивним шляхом та проводять оцінку їх фізико-хімічних і біохімічних показників в нормі та при захворюваннях, визначаються їх референтні значення дослідження (Меньшиков \& Лукичева, 1996; Lindsay \& Wolfe, 2020; Mena-Bravo \& De Castro, 2014).

Так, за даними авторів (Baker, Stofan, Hamilton \& Horswill. 2009) для збору проб поту 
часто застосовується метод абсорбуючого пластиру для лабораторних досліджень концентрації електролітів в ньому. Проте, ця методика має свої недоліки. Зокрема, покриття поверхні шкіри пластиром пригнічує випаровування поту під ним, а склад та швидкість виділення поту відрізняються в різних ділянках тіла. До того ж, якщо розглядати дану методику відбору поту у військовослужбовців ССО, то такий пластир не зручний у використанні разом зі спецспорядженням чи наплічником та може обмежувати рухи в ході виконання вправ.

Іншим досить точним вважається метод змивання поту з усього тіла Whole body washdown (WBW), оскільки піт збирається 3 усієї площі тіла. 3 цих причин метод WBW рекомендується застосовувати при проведенні досліджень балансу поживних речовин або під час визначення загальної втрати мікроелементів чи інших компонентів через потовиділення. Проте, даний метод є громіздким, скрупульозним та дороговартісним, оскільки вимагає добре контрольованих лабораторних умов (закритої спеціальної камери) та точного режиму перевірки фізичних навантажень за допомогою велоергометрії (Baker \& Wolfe 2020), що також $є$ неможливим в нашому випадку.

Найчастіше при проведенні досліджень практикується збір поту з однієї або декількох невеликих ділянок тіла за допомогою вбираючих прокладок, паперових фільтрів, бавовняної білизни або рушників. В подальшому, просочені потом матеріали замочують у дистильованій воді, з метою виокремлення різних компонентів, далі випарюють екстракт у вакуумі та проводять аналіз (Селезнева \& Иванцова, 2019; Taylor \& Machado-Moreira, 2013).

В дослідженні (Ярушин, 2017) паралельно проводився відбір та дослідження різних компонентів як слини, так і поту. Свою ефективність показав метод відбору проб поту 3 допомогою паперового фільтру ( $\mathrm{d}=40$ мм). $\mathrm{B}$ поті визначалася кількість лейцину і треоніну методом паперової хроматографії. У слині, в свою чергу, визначалися - $\mathrm{pH}$, амілазна активність, аланін та лейцин. Вказані показники ви- значалися до та після навантажень, а фізичні навантаження були розділені за чотирма ступенями інтенсивності:

1) щадний (ЧСС 90-100 уд./Хв);

2) легкий (ЧСС 110-130 уд./хв);

3) середній (ЧСС 140-150 уд./хв);

4) високий (ЧСС 160-170 уд/Хв).

В результаті даного дослідження встановлено, що перші три ступеня навантаження викликають підвищення кількості досліджуваних амінокислот в поті та слині, зниження активності амілази та наближення $\mathrm{pH}$ слини до фізіологічної норми 7,4-7,8.

При високо інтенсивних навантаженнях збільшувалася різниця розмаху результатів, що, ймовірно, пов'язано з різною індивідуальною адаптацією до фізичних навантажень. В результаті кількість амінокислот в слині збільшувалася більш помірно в одній третій випадків. В решти проб кількість амінокислот знижувалася, що розцінювалося як досягнення цими особами граничних для них навантажень.

В осіб, що мали хорошу фізичну підготовку (займалися спортом, ІГСТ $\geq 90, \mathrm{PWC170 \geq}$ 1400), виявлені наступні особливості:

1. кількість амінокислот в поті по відношенні до легких навантажень було вище, ніж в інших;

2. підвищення вмісту амінокислот в слині було більш значним;

3. активність амілази знижувалась помірНо;

4. рівень $\mathrm{pH}$ слини після навантажень був в межах фізіологічної норми.

У студентів з низьким рівнем тренованості (ІГСТ $\leq 60$, РWC170 $\leq 1099)$ відмічаються наступні особливості:

1. кількість амінокислот в поті по відношенню до їх вмісту при легких навантаженнях була нижча, ніж у осіб, хто мав хорошу фізичну підготовку;

2. при виконанні високо інтенсивних навантажень кількість амінокислот в слині знижувалася;

3. зафіксовано значне зниження амілази;

4. рівень $\mathrm{pH}$ слини після високо інтенсивних навантажень зміщувався в лужну сторону $-\mathrm{pH} \geq 8,0$. 
Отож, нашу увагу привернув саме цей метод збору проб поту на паперові фільтри, як найбільш оптимальним щодо застосування під час Q-курсу. Як вказано у вище зазначеній роботі, підтверджено ефективність даного методу - встановлені референтні значення при різних видах навантажень.

Аналіз джерел літератури підтверджує, що застосування неінвазивних методів, в умовах інтенсивних навчально-тренувальних навантажень Q-курсу, є найбільш зручним, оскільки відбір матеріалу може проводитися в процесі виконання завдань без втручання в режим підготовки курсантів та не потребуватиме залучення спеціально навчених медичних працівників (як при взятті проб крові). До того ж, одночасно може здійснюватися відбір великої кількості проб (Мякишева, Колсанов, Власов \& Соколов, 2017), а результати отриманих досліджень дозволять приймати управлінські рішення щодо корекції інтенсивності чи тривалості фізичних навантажень в ході відбору на Q-курсі (Ярушин, 2017; Осіпов, 2013).

Проте, питання залежності змін хімічного складу поту чи слини від характеру навантажень і рівня тренованості на сьогоднішній день потребує подальшого вивчення. Понад усім, нам не вдалося у відкритих джерелах літератури відшукати даних щодо застосування подібних методів під час Q-курсу в арміях зарубіжних країн.

Висновки. За даними літератури встановлено, що виснажливі фізичні та психологічні навантаження в організмі можуть призводити до активації перекисного окиснення ліпідів 3 пошкодженням клітинних мембран та загрозою віддалених вільнорадикальних патологічних станів.

Вивчення впливу фізичних навантажень на процеси перекисного окислення ліпідів в організмі кандидатів під час проходження Q-курсу могло би стати в майбутньому підгрунтям 3 розробки критеріїв оцінки спроможності військовослужбовців до виконання завдання за призначенням в надскладних умовах при подальшій службі в ССО.

В умовах інтенсивних навчально-тренувальних навантажень Q-курсу, застосування неінвазивних методів відбіру біологічних рідин, зокрема поту та слини, може мати ряд переваг, оскільки може здійснюватися безпосередньо в процесі виконання завдань - без втручання в режим підготовки курсантів, не потребуватиме залучення спеціально навчених медичних працівників, а також з одночасним відбором великої кількості проб.

Конфлікт інтересів - відсутній.

Фінансування - дана стаття не отримувала зовнішнього фінансування.

\section{ЛІТЕРАТУРА}

Афонина, Г. Б., \& Куюн, Л. А. (2000). Липиды, свободные радикалы и иммунный ответ. К.: НМУ, 285.

Варус, В. І., Брюзгіна, Т. С., Белов, О. А., Соловська, С. С., \& Депутат, Ю. М. (2007). Зміни ліпідних показників у поті осіб, діяльність яких пов'язана з військовою службою. Доповіді Національної академії наук України, (1), 175-178.

Варус В.І., Іванов Д.А., Брюзгіна Т.С., Депутат Ю.М., Швець А.В. (2010). Вивчення змін ліпідного метаболізму крові і поту у військовослужбовців з дезадаптаційними зривами // Зб. наук. праць співробітників НМАПО імені П.Л. Шупика. - С. 66-70.

Волков, Н. И., Несен, Э. Н., Осипенко, А. А., \& Корсун, С. Н. (2000). Биохимия мышечной деятельности.

Говоруха, О. Ю., \& Шнайдерман, О. Ю. (2016). Значення взаємодії перекисного окиснення ліпідів і антиоксидантних систем в розвитку патологічних процесів. Експериментальна і клінічна медицина, (4), 10-14.

Гоженко, А. И., Зацерклянный, А. М., \& Цепколенко, В. А. (2006). Современные представления о строении и функции секреторно-экскреторного аппарата кожи человека. Дерматовенерология. Косметология. Сексопатология, (3-4 (9)).

Горіла, М. В. (2009). Неінвазивні методи діагностики-стан проблеми та перспективи розвитку. Biosystems Diversity, 17(1), 38-43.

Депутат, Ю. М., \& Гуліч, М.П. (2020) Дослідження добових енерговитрат військовослужбовців Сил спеціальних операцій Збройних Сил України. Довкілля та здоров’я, (3), 32-39.

Коломеец, Н. М., Новоженов, В. Г., Белоногов, М. А., \& Волчек, И. А. (1997). Влияние экстремальных факторов экологии на резистентность здорового человека. Военно-медицинский журнал, (5), 49-53. 
Лізогуб В.Г., Пануша І.А, Брюзгіна Т.С. Патент на корисну модель №78640 від 2016 р. Спосіб визначення порушень ліпідного метаболізму у хворих на ішемічну хворобу серця.

Лихорад, Е. В., \& Шаковец, Н. В. (2013). Слюна: значение для органов и тканей в полости рта в норме и при патологии.

Мелешко В.І., Самошкін В.В. Біохімічна діагностика в спорті. (2015). Дніпро, ДДІФКіС, (280) - с.183.

Меньшиков, В. В., \& Лукичева, Т. И. (1996). Проблемы неинвазивной диагностики в клинической лаборатории: материалы исследования и методы. Клиническая лабораторная диагностика, (4), 33.

Мохан, Р., Глессон, М., \& Гринхафф, П. Л. (2001). Биохимия мышечной деятельности и физической тренировки: пер. с англ. Олимпийская литература.

Мусієнко О.В., Крапівіна К.О., Павлишин О.Ф., Козак І.В., Савка І.В. Зміни показників перекисного окиснення ліпідів та активності антиоксидантної системи протягом річного циклу оздоровчих тренувань (2009) Львівський національний університет імені Івана Франка.

Мякишева, Ю. В., Колсанов, А. В., Власов, М. Ю., \& Соколов, А. В. (2017). Неинвазивная диагностика состояния обменных процессов в организме: маркеры ротовой жидкости. Современные проблемы науки и образования, (5), 14.

Орел Н.М. Биохимия мембран. (2010). Метод. пособие к лабораторным занятиям для студентов биологического факультета Мн.: БГУ. - 28 с.

Осипенко, Г. А. (2007). Основи біохімії м’язової діяльності.

Осіпов, В. М. (2013). Спортивна медицина.

Остапченко Л. І., Синельник Т. Б., Компанець І. В. (2016). Біологічні мембрани та основи внутрішньоклітинної сигналізації. Теоретичні аспекти: навч. посіб. - К.: ВПЦ «Київський університет», - 639 с.

Петрина, С. Н., \& Юшина, Л. В. (1989). Роль липидов в адаптационных реакциях организма на экстремальные воздействия. Патол. физиология. и эксперим. терапия, (2), 51-53.

Петрачков, О.В. (2014). Фізична підготовка, як фактор прискореної адаптації військовослужбовців до бойової діяльності в умовах жаркого клімату. Збірник наукових праць “Вісник Національного університету оборони України" - К.: НУОУ, 135-138.

Романчук, С. В., Мицкан, Б. М., Афонін, В. М., Лойко, О. М., Пилипчак, І. В., Кузнецов, М. В., \& Лісовський, Б. П. (2018). Вплив спортивних єдиноборств на удосконалення спеціальної фізичної підготовленості військовослужбовців.

Селезнева, И. С., \& Иванцова, М. Н. (2019). Биохимические изменения при занятиях физкультурой и спортом: учебное пособие.

Трохимович А.А., Кишко М.М., Сливка Я.І., Ганич О.Т. (2011) Вільнорадикальне окиснення і антиоксидантна система в серцево-судинній патології. Ужгородський національний університет.

Фабрі 3.Й., Чернов В. (2014). Біохімічні основи фізичної культури і спорту: Навчальний посібник. - Вид. 2-е, доп. і перероб. - Ужгород: Ужгородський національний університет.

Фуртес, О. О., \& Ткачук, Д. А. (2010). Комплектування сил спеціальних операцій: передовий досвід іноземних армій.

Шахлина, Л. Г., Коган, Б. Г., Терещенко, Т. А., Тищенко, В. П., \& Футорный, С. М. (2016). Спортивная медицина.

Ярушин, С. А. (2017). Влияние физических нагрузок различной интенсивности на изменение некоторых биохимических показателей в поте и слюне. Физическая культура. Спорт. Туризм. Двигательная рекреация, 2(4).

Ясенчук В. Н. (2018). Фізична підготовка військовослужбовців ССО в умовах українсько-російського протистояння. Humanitarium, 40(2), 143-154.

Agrawal, K., Sivamani, R. K., \& Newman, J. W. (2019). Noninvasive profiling of sweat-derived lipid mediators for cutaneous research. Skin Research and Technology, 25(1), 3-11.

Agrawal, K., Hassoun, L. A., Foolad, N., Pedersen, T. L., Sivamani, R. K., \& Newman, J. W. (2017). Sweat lipid mediator profiling: a noninvasive approach for cutaneous research. Journal of lipid research, 58(1), 188-195.

Baker, L. B., \& Wolfe, A. S. (2020). Physiological mechanisms determining eccrine sweat composition. European journal of applied physiology, 1-34.

Baker, L. B., Stofan, J. R., Hamilton, A. A., \& Horswill, C. A. (2009). Comparison of regional patch collection vs. whole body washdown for measuring sweat sodium and potassium loss during exercise. Journal of Applied Physiology, 107(3), 887-895)

Calderón-Santiago, M., Priego-Capote, F., Jurado-Gámez, B., \& de Castro, M. L. (2014). Optimization study for metabolomics analysis of human sweat by liquid chromatography-tandem mass spectrometry in high resolution mode. Journal of chromatography A, 1333, 70-78. 
Deuster P., Kemmer T., Tubbs L. et al. The Special Operations Forces Nutrition Guide. 2016, 215 P.

Delgado-Povedano, M. M., Calderón-Santiago, M., de Castro, M. L., \& Priego-Capote, F. (2018). Metabolomics analysis of human sweat collected after moderate exercise. Talanta, 177, 47-65.

Krsota VM. Spetsialna fizychna pidhotovka ofitseriv cherhovoho boyovoho rozrakhunku komandnoho punktu ViyskovoMorskykh Syl Ukrainy: avtoref. dis. ... kand. nauk physical education and sport, Abstr. PhDr. (Physical Education and Sport). Kh, 2007. 20 s. [Ukrainian].

Kand’ár, R., Drábková, P., Andrlová, L., Kostelník, A., \& Čegan, A. (2016). Determination of selected fatty acids in dried sweat spot using gas chromatography with flame ionization detection. Journal of separation science, 39(22), 43774383.

Islamov, V. A., Dmitriev, G. G., Bogza, K. A., \& Tsygankov, R. A. (2016). Adaptation mechanisms of servicemen to extreme environments. Theory and Practice of Physical Culture, (2), 20-20.

Lindsay B. Baker and Anthony S. Wolfe. Physiological mechanisms determining eccrine sweat composition (2020).

Mena-Bravo, A., \& De Castro, M. L. (2014). Sweat: a sample with limited present applications and promising future in metabolomics. Journal of pharmaceutical and biomedical analysis, 90, 139-147.

Montain, S. J., \& Young, A. J. (2003). Diet and physical performance This review contributes to a Special Section on US Army Research, guest-edited by ML Meiselman, FM Kramer, J. Soyer and P. Pliner. Appetite, 40(3), 255-267.

Romanchuk SV, Starchuk AA, Romanchuk VN, i dr. Mesto i znachenie fizicheskoy podgotovki v sisteme podgotovki spetsialistov. Fizicheskoe vospitanie student

Taylor, N. A., \& Machado-Moreira, C. A. (2013). Regional variations in transepidermal water loss, eccrine sweat gland density, sweat secretion rates and electrolyte composition in resting and exercising humans. Extreme physiology \& medicine, 2(1), 1-30.

Viru, A. (2017). Adaptation in sports training. Routledge.

Zolotareva, L. V., \& Volchkova, V. I. (2015). Adaptation of athletes after completing the sports career. In Современные проблемы и перспективы развития системы подготовки спортивного резерва в преддверии XXXI Олимпийских игр в Рио-Де-Жанейро (pp. 180-181). 


\section{ИЗУЧЕНИЕ ОПЫТА \\ ПРИМЕНЕНИЯ НЕИНВАЗИВНЫХ МЕТОДОВ ДЛЯ ОЦЕНКИ ФУНКЦИОНАЛЬНОГО СОСТОЯНИЯ ОРГАНИЗМА ПРИ ФИЗИЧЕСКИХ И ПСИХОЭМОЦИОНАЛЬНЫХ НАГРУЗКАХ (обзор литературы)}

\section{Жалдак Анастасия ${ }^{1}$, Иванько Олеся ${ }^{2}$, Депутат Юрий ${ }^{3}$}

${ }^{1}$ Старший врач отделения санитарно эпидемиологического надзора санитарноэпидемиологического отдела войсковой части A4520, г. Львов, Украина

${ }^{2}$ Начальник Научно-исследовательского института проблем военной медицины Украинской военно -медицинской академии, г. Киев, Украина

${ }^{3}$ Ведущий научный сотрудник Научноисследовательского института проблем военной медицины Украинской военномедицинской академии, г. Киев, Украина

Аннотация. В обзоре литературы рассмотрены вопросам особенностей профессиональной деятельности военнослужащих нового рода войск - Сил специальных операций Вооруженных Сил Украины, в частности, при отборе и подготовке специалистов на квалификационном курсе специальных операций Вооруженных Сил Украины. Обобщены данные литературы относительно реакций организма на физические и психоэмоциональные нагрузки. При этом обращается внимание, что результатом первичного метаболического ответа организма на экстремальные факторы (физические нагрузки и стресс) является активация свободно радикального окисления липидов мембран. Биохимическим маркером активации этого процесса могут служить полиненасыщенные жирные кислоты, а их качественные и количественные изменения в биологических жидкостях характеризуют функциональное состояние организма при физических и психоэмоциональных нагрузках.
STUDYING THE EXPERIENCE OF APPLICATION

OF NON-INVASIVE METHODS

TO ASSESS THE FUNCTIONAL STATE OF THE ORGANISM

UNDER PHYSICAL

AND PSYCHOEMOTIONAL LOADS

(literature review)

\section{Zhaldak Anastasiia ${ }^{1}$, Ivanko Olesia ${ }^{2}$, Deputat Yurii ${ }^{3}$}

${ }^{1}$ Senior doctor of sanitary-epidemiological surveillance section ofsanitaryepidemiological department of A4520 military unit, Lviv, Ukraine

${ }^{2}$ Chief of Research Institute of Military Medicine of Ukraine Military Medical Academy, Kyiv, Ukraine

${ }^{3}$ Leading researcher of Research Institute of Military Medicine of Ukraine Military Medical Academy, Kyiv, Ukraine

Summary. In the literature review considered of professional work of servicemen of Special Operations Forces of Armed Forces of Ukraine with accent on qualification course of Special Operations Forces have been reviewed. Based on available scientific reports, mechanisms of adaptive reactions of organism to physical and mental loads have been summarized. The literature data on the organism reactions to physical and psycho-emotional stress are summarized. It was pointed out that the result of primary metabolic response of organism for extreme physical loads and stress is activation of free radical oxidation of membranes' lipids. Biological marker of this process activation may be polysaturated fatty acids and their qualitative and quantitative changes in biological fluids characterize functional state of organism during physical and mental loads.

Systemization of literature sources and approaches to solve problem of use of noninvasive analysis of biological fluids indicated that based on biochemical analysis of biological fluids there is an opportunity to reveal the level of activation of lipid peroxidation i.e. adaptive reactions of organism. 
Систематизация литературных источников и подходов к решению проблемы применения неинвазивных методов исследования биологических жидкостей показала, что на основе данных биохимического исследования этих жидкостей можно охарактеризовать уровень активации перекисного окисления липидов, то есть приспособительных реакций в организме.

Ключевые слова: военнослужащие, физические нагрузки, перекисное окисление липидов, неинвазивные методы, биологические жидкости.
Key words: servicemen, physical exercise, lipid peroxidation, non-invasive methods, biological fluids 